\title{
Reframing Ethos Rhetorical Criticism
}

\author{
Wang Niu, Yuan Ying* \\ School of Foreign Languages, Soochow University, China
}

Copyright (C) 2016 by authors, all rights reserved. Authors agree that this article remains permanently open access under the terms of the Creative Commons Attribution License 4.0 International License

\begin{abstract}
This paper aims at constructing a hierarchical system of ethos category, which is expected to be more operable and interpretive in both rhetorical criticism and rhetorical practice. The justification of this ethos system is the focus of the inquiry. We will mainly resolve the vagueness of Aristotle's three elements of ethos: good sense, good moral character and goodwill, via extracting from the existing studies some core subelements for each of them. To achieve this objective, the related chapters in Aristotle's Rhetoric are reexamined; interpretations of ethos by contemporary scholars are investigated; and two texts from different genres are analyzed for the testing of this reframed ethos model.
\end{abstract}

Keywords Ethos, Rhetorical Criticism, Good Sense, Good Moral Character, Goodwill

\section{Introduction}

Since the mid-20th century, ethos has become a hot topic in America and European countries. The studies on the origin, definition and evolution of this concept constitute an important part of the theoretical inquiry. Sattler (1947) [1] pointed out that usages, habits and traditions separating one community from others seem to be the original meanings of ethos. Halloran (1982) [2] shared a similar view that ethos manifests the virtues most valued by a culture, and that in modern society, ethos can be a community, a culture and a historical period. Frobish (2003) [3] attempted to identify the core components of a theory of character in Iliad and explained how this epic might have affected Aristotle's ethos. Kennedy (2007) [4] held that the predominant meaning of ethos for Aristotle is "moral character". However, the term can also refer to qualities "with which individuals may be naturally endowed and which dispose them to certain kinds of action" (Aristotle, 2007, p. 163). Brahnam (2009) [5] saw ethos as the synonym of character, reputation, persona in classical literature, self and subject in modern context.

Compared with the theoretical study of ethos, the application of this concept has received more attention. Kallendorf \& Kallendorf (1985) [6] explored the contribution of ethos to business communication. They held that figures of speech are the tools for building an effective verbal ethos of intelligence, upright character and good will. Dean (2005) [7] studied the use of ethos as an important means of persuasion during the UK 2005 General Election. Cheng (2012) [8], with a broad understanding of ethos, illustrated how Colin Powell reconstituted his ethos in his 2003 pre-war speech to the UN. Shanahan \& Seele (2015) [9] demonstrated how Aristotle's ethos helps underpin substantive and procedural recommendations for corporate reputation management. In addition to business, politics and military affairs, education is another major field for ethos' application. Halloran (1982) tried to prove that a theory of ethos or character is an important need for teachers of composition. Jorgensen (2000) [10] argued that a college campus is an ethos and, apart from intellectual faculty, moral virtue should be taught in college because real learning is learning to love, and love shapes virtue. Brahnam (2009) examined the concept of ethos as it functions in oral and written discourses and explored what happened to ethos in computer-mediated human-to-human and human-to-machine discourses.

Researches on ethos in China are also noteworthy. Scholars have explored it from the perspectives of rhetorical history, comparative rhetoric, and the application of ethos. Liu (2004) [11], after examining ethos in Aristotle, Cicero, Quintilian and George Campbell, argued that ethos is not necessarily the natural display of personality, but rather a construction to suit the rhetorical situation. Gong (1994) [12] compared the concept of "zheng ming" in ancient China with Aristotle's ethos and elaborated the role of speakers in the process of persuasion by introducing the modern referents of ethos. Fan (1999) [13] made a comparison of the three appeals in persuasion between Western and ancient Chinese rhetorics. Lan (2010) [14] illustrated how a speaker can build and keep up his positive image throughout a rhetorical process by analyzing the beginning of Cao Xueqin's $A$ Dream of Red Mansions and the preface of Samuel Johnson's English Dictionary. Tu (2007) [15] combined Perelman's concept of "presence" with Aristotle's ethos to analyze the rhetorical devices of American news reporting of a US military plane destroying a Chinese military aircraft in 2001. Li \& Liu (2011) [16] studied the interaction between 
authority, ethos and persuasion by analyzing a motor advertisement. Ju (2013) [17] attempted to explain how metadiscourse is applied to achieve the three appeals in academic papers. There are many more researches analyzing ethos or the three appeals in various text types.

As stated above, contemporary scholars have already carried out various theoretical and applied researches on ethos. These investigations have greatly contributed to the development of this concept. However, the majority of them are based on the general understanding of this concept, which results in vague explanations. It is necessary for us to explore the specific referents of ethos. Therefore, this study, from the perspective of rhetorical criticism, focuses on clarifying the elements and subelements of ethos, establishing a model of ethos rhetorical criticism and justifying the model through discourse analyses.

\section{A Reframed Model of Ethos}

\subsection{Elements and Subelements of Ethos}

Though Aristotle once said "his character may almost be called the most effective means of persuasion he possesses"(Aristotle, 1954, p. 25) [18], he explained little about ethos in his Rhetoric. In Chapter 1 of Book II, he simply mentioned some basic elements of ethos. According to him, there are three reasons why speakers themselves are persuasive: "good sense, good moral character and goodwill" (ibid, p. 91). However, he did not elaborate the content of each element. For good sense and good moral character, a note was given for readers to refer to Chapter 9 of Book I, which did not separately explain the two aspects; instead, the nine subdivisions of virtue were discussed: "justice, courage, temperance, magnificence, magnanimity, liberality, gentleness, prudence, and wisdom"(ibid, p. 57). From them we think it proper to extract the first four major virtues as the subelements of good moral character and the last two as those of good sense. In Rhetoric, the discussion of goodwill is related to friendliness, but Aristotle did not explore the content of goodwill, either. The note given refers to Chapter 4 of Book II, which mainly defines friendliness and friends; therefore, we just vaguely understand his goodwill as "friendliness". It can be concluded that Aristotle clearly defined three elements for ethos, but his explanation of them, especially that of good sense and goodwill, is still obscure, which, to some extent, has weakened the operability and interpretiveness of this concept.

As rhetorical situation changes and rhetoric as a discipline develops, contemporary scholars began to reconsider the concept of ethos and the subdivision of its elements and made an abundance of research findings. Hovland et al (1953) [19] analyzed the components of credibility, which is often a substitute of ethos, and pointed out that ethos involves expertness, trustworthiness, and the rhetor's intention toward the receiver, which correspond to good sense, good moral character and goodwill. The meanings of these three elements seem rather clear, but much narrower than those of Aristotle's.

McGuire (1985) [20] reexamined the elements of ethos and claimed that ethos has three important components: credibility, attractiveness and authority. His credibility includes two aspects: expertise and reliability. Expertise can be seen as included by Aristotle's good sense, while reliability actually, refers to goodwill, for it means whether the speaker is willing to deliver true views or whether the motivation of the speaker is reliable. Attractiveness includes the appearance of the speaker, the disposition and moral character acquired from his experience, and the features presented by clothes, manners, speeches, accents and so on. Authority mainly refers to the speaker's power or ability of rewarding and punishing people. In the frame of Aristotle's three dimensions, McGuire's authority and expertise in credibility belong to good sense, attractiveness can be included in good moral character, while the reliability of motivation in credibility should be one aspect of goodwill.

Cockcroft \& Cockcroft (1992) [21] examined ethos by focusing on what they regarded as its main components: personality and stance. Speaker's ability to identify with his audience or his individuality to impress them is central to the communication of personality. Image, which is seen as a powerful force in modern society and which includes personal image, corporate identity and political charisma, is also a significant part of personality. Stance is a general term mainly involving attitudes, the sense of a position or a viewpoint adopted by the persuader. Responding to Aristotle's framework, we perceive personality (individuality, image) as within the dimension of good moral character and stance (attitude, viewpoint) as within that of good sense. However, their study seems not to have explored the dimension of goodwill.

Crowley \& Hawhee (1994) [22] systematically elaborated how a speaker can demonstrate his intelligence, establish good character and achieve good will in the chapter of "Ethical Proof". According to them, to demonstrate intelligence, the speaker should seem well informed about the issue at hand by suggesting he is an insider, by indicating he has experience or knowledge in a particular area, by describing his qualifications or by demonstrating his adeptness in a particular field. In order to establish good character, rhetors should try to show their qualities of intelligence, honesty, and trustworthiness. To express good will, modern rhetors should carefully consider what audiences need to know about the issue at hand in order to follow the argument or why they think their presentation of an argument is important, and what will benefit those who read or listen to it. It can be found that quality of "intelligence" in establishing good character overlaps with "intelligence" in the first aspect; therefore, the former may better be omitted. The rest of the elaboration can be seen as the detailed explanation of Aristotle's three elements.

McCroskey \& Teven (1999) [23] examined the research of this concept from the mid-1960s to the early 1980s and concluded that most of these studies observed the 
dimensions of "competence" and "trustworthiness". The former includes qualification, expertness, intelligence and authoritativeness, while the latter includes character, sagacity, safety and honesty. However, the dimension of "goodwill" or "intent toward receiver" was ignored. In fact, McCroskey (1992) [24] advanced the "perceived caring" construct, which is an expression of goodwill. He suggested that three elements may result in a person being seen as more caring: understanding, empathy, and responsiveness. Understanding is knowing another person's ideas, feelings, and needs. Empathy is one person's identification with another person's feelings. Responsiveness involves one person acknowledging another person's communicative attempts. By integrating, we can respectively put McCroskey $\&$ Teven's summary of previous studies (competence and trustworthiness) and McCroskey's own study of "caring" under the three dimensions of good sense, good moral character and goodwill.

In Chapter 10, "Role Criticism", Hart \& Daughton (2005) [25] introduced a method of rhetorical criticism about ethos. They replaced "ethos" with "credibility" and provided the revised "Verbal Dimensions of Credibility" by Hart et al (1983) [26]. There are six dimensions in the chart: power (rewarding and punishing the audience), competence (knowledge and experience), trustworthiness (long-term reliability), good will (having the best interests of the audience in mind), idealism (possessing qualities aspired to by the audience), and similarity (resembling the audience in important ways). Based on the three dimensions of Aristotle, power and competence can be put in the dimension of good sense, trustworthiness and idealism belong to that of good moral character, and good will and similarity are in the dimension of goodwill.

Brahnam (2009) paraphrased Aristotle's "good sense” as "practical intelligence", "expertise", and "appropriate speech". The word "excellence" in the article actually refers to "good moral character", which was claimed to include "socially sanctioned virtues" and "truth telling". He also explained "goodwill" as "keeping the welfare of the user in mind".

In order to clearly show the elements of ethos and their respective referents given by past researches, the following table is to summarize the related seven studies mentioned above from Hovland et al (1953) to Brahnam (2009). It can be found that their clarifications of those elements are mainly the further explanation and extension of Aristotle's theory; therefore, basically they can be put under the three dimensions of Aristotle's ethos.

\section{Elements and Subelements of Ethos}

\begin{tabular}{|c|c|c|c|}
\hline Aristotle & $\begin{array}{l}\text { Good sense } \\
\text { prudence } \\
\text { wisdom }\end{array}$ & $\begin{array}{c}\text { Good moral character } \\
\text { justice } \\
\text { courage } \\
\text { temperance } \\
\text { magnificence } \\
\end{array}$ & $\begin{array}{l}\text { Goodwill } \\
\text { friendliness }\end{array}$ \\
\hline Hovland et al & expertness & trustworthiness & intention toward the receiver \\
\hline McGuire & $\begin{array}{l}\text { expertise } \\
\text { authority } \\
\text { rewarding } \\
\text { punishing }\end{array}$ & $\begin{array}{l}\text { attractiveness } \\
\text { appearance } \\
\text { disposition } \\
\text { moral character } \\
\ldots\end{array}$ & reliability of motivation \\
\hline $\begin{array}{c}\text { Cockcroft \& } \\
\text { Cockeroft }\end{array}$ & $\begin{array}{c}\text { stance } \\
\text { attitude } \\
\text { viewpoint }\end{array}$ & $\begin{array}{l}\text { personality } \\
\text { individuality } \\
\text { image } \\
\end{array}$ & \\
\hline $\begin{array}{c}\text { Crowley \& } \\
\text { Hawhee }\end{array}$ & $\begin{array}{l}\text { intelligence } \\
\text { experience } \\
\text { adeptness }\end{array}$ & $\begin{array}{l}\text { good character } \\
\text { honesty } \\
\text { trustworthiness }\end{array}$ & $\begin{array}{c}\text { good will } \\
\text { considering audience's needs } \\
\text { benefiting audience }\end{array}$ \\
\hline $\begin{array}{c}\text { McCroskey \& } \\
\text { Teven }\end{array}$ & $\begin{array}{c}\text { competence } \\
\text { qualification } \\
\text { expertness } \\
\text { intelligence authoritativeness }\end{array}$ & $\begin{array}{l}\text { trustworthiness } \\
\text { character } \\
\text { sagacity } \\
\text { safety } \\
\text { honesty } \\
\end{array}$ & $\begin{array}{c}\text { goodwill/perceived caring } \\
\text { understanding } \\
\text { empathy } \\
\text { responsiveness }\end{array}$ \\
\hline $\begin{array}{c}\text { Hart \& } \\
\text { Daughton }\end{array}$ & $\begin{array}{c}\text { power } \\
\text { rewarding and punishing } \\
\text { audience } \\
\text { competence } \\
\text { knowledge and experience }\end{array}$ & $\begin{array}{c}\text { trustworthiness } \\
\text { long-term reliability } \\
\text { idealism } \\
\text { possessing qualities aspired to by } \\
\text { the audience }\end{array}$ & $\begin{array}{l}\text { good will } \\
\text { having the best interests of } \\
\text { audience in mind } \\
\text { similarity } \\
\text { resembling audience in } \\
\text { important ways }\end{array}$ \\
\hline Brahnam & $\begin{array}{c}\text { good sense } \\
\text { practical intelligence } \\
\text { expertise } \\
\text { appropriate speech }\end{array}$ & $\begin{array}{l}\text { excellence } \\
\text { socially sanctioned virtues } \\
\text { truth telling }\end{array}$ & $\begin{array}{l}\text { goodwill } \\
\text { keeping the welfare of } \\
\text { audience in mind }\end{array}$ \\
\hline
\end{tabular}




\subsection{A Hierarchical Model of Ethos}

According to this table, contemporary scholars generally based their understanding of ethos on Aristotle's three elements, while only some changed them into two elements (like Cockcroft \& Cockcroft) or more than three (like Hart \& Daughton). It is considered that two elements suggested by the former are relatively vague and obscure, which cannot fully represent the content of ethos, and although the latter suggested more than three dimensions, they can be covered by the three aspects of Aristotle's ethos theory. Therefore, we hold that it is desirable to have three elements in the category of ethos, which can not only ensure the completeness of its content, but also guarantee the conciseness of the whole system so that difficulties in memory and operation can be avoided. As for the names of the three elements, we can continue to use "good sense", "good moral character" and "goodwill" in Aristotle's theory so that the concept of ethos will be well inherited and easily grasped. On the other hand, the subelements of the three aspects should be further specified to avoid randomness. Inspired by the three-dimension concept analysis method, this paper will also extract three subelements for good sense, good moral character and goodwill. The major criterion of extraction is that those components are identified by several scholars and the three elements and their subelements are in hyponymy relations, while the three subelements of each element are logically at the same level so that the reframed model can overcome any kinds of logical disorder.

Based on the views above, the following extractions are made. For good sense, the three subelements are: experience, expertise and authority, which contain specific and logically differentiable meanings. "Experience" was put forward by Crowley \& Hawhee and Hart \& Daughton to mean that the speaker has enough experience and knowledge to prove that he is well informed about the situation. Broadly speaking, "prudence", "wisdom", "intelligence" and "practical intelligence" mentioned by others can all be included in "experience". "Expertise" appears twice in the table, and its importance can also be seen from "expertness", "adeptness" and "qualification". "Authority", considered as a variation of ethos by Farrell (1993) [27], was also attached importance to by McGuire, McCroskey \& Teven and Hart \& Daughton who used "power" instead of "authority". Here "authority" means the ability to reward and punish the audience, and act as a role of influencing their choices.

For components of "good moral character", we should keep "justice" as the first choice, for it is the first virtue acknowledged by Aristotle, and the frequently proposed "trustworthiness" is similar to "justice" in meaning. We would also choose "honesty" (truth-telling) for at least three researches have clearly put it in the list. Another factor which has successfully drawn attention of contemporary scholars is "appearance" or "image", which in fact, is similar to Aristotle's "magnificence". This paper chooses to use "stateliness" as a substitute of "magnificence", so that it is logically matched with "justice" and "honesty" and at the same time much more appropriate when describing a speaker. Because of the extensiveness of good moral character, many other virtues could have been included, which leaves this model open to potential change.

As for the subelements of goodwill, we find that McCroskey \& Teven's "caring" is rather comprehensive: understanding, empathy, and responsiveness. "Understanding" means knowing another person's ideas, feelings, and needs, which is similar to "considering audience's needs". "Empathy" means one person's identification with another person's feelings, which contains "friendliness", "similarity" and "intention toward the receiver". "Responsiveness" means one person acknowledging another person's communicative attempts and is judged by how active the speaker is in the communication, which may include "benefiting audience" and "keeping the welfare of audience in mind". Therefore, it is reasonable to conclude that those suggested by other scholars concerning goodwill can almost be included in the three factors. Below is our reframed model of ethos:

\section{A Reframed Model of Ethos}

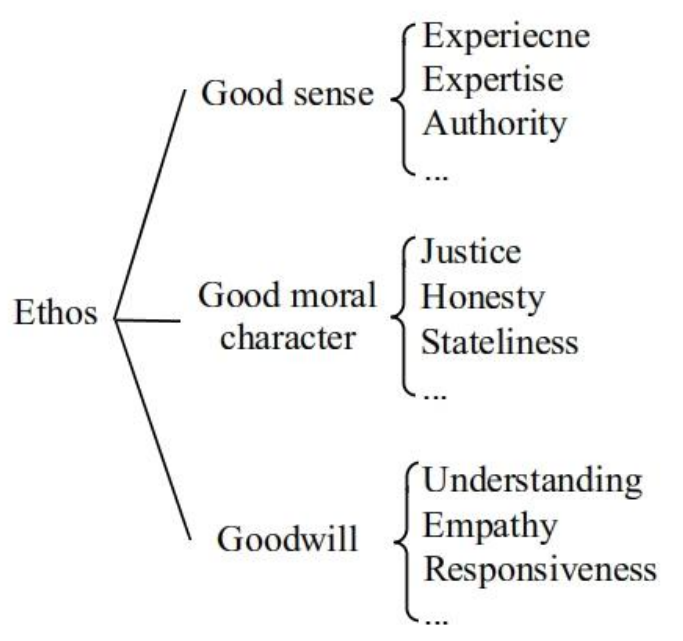

This new interpretation of ethos is based upon a detailed analysis of Aristotle's three elements and a prudent examination of researches by contemporary scholars. The choice of elements and subelements follows the two principles of hierarchies in semantics: "Longitudinal direction should be in relation of dominance, horizontal direction in relation of difference"(Shu, 2000, p. 73) [28]. This hierarchical system has avoided overlapping of meanings between elements and their subelements, and between the extracted subelements lie identifiable differences. Although the reframed model, developing from Aristotle and contemporary rhetoricians, has its logical basis, this hierarchical system is open, especially in the number of the third level which can be added or reduced, as indicated in the diagram by the marks of set and ellipsis. We suggest that in application, the three elements be all tended to, for Aristotle soundly concludes, "any one who is thought to have 
all three of these good qualities will inspire trust in his audience" (1954: 91), while the subelements be selected or added or modified according to the specific rhetorical situation, especially the characteristics of the target audience.

\section{Application of the Reframed Ethos Model}

In this part, the new model of ethos will be applied to rhetorical criticism. To test its operability, an advertisement and a speech are selected. The selection of texts is by no means casual; instead, it is in accordance with the principle of qualitative research and its method of purposive sampling, which aims at selecting research objects with maximum information available for the research questions. In this study, our research object is text; we thus choose two different types of texts, to be substantially analyzed via elements and subelement of the reframed ethos model.

\subsection{Advertisement of BedMATCH}

BedMATCH is a patented diagnostic system that can judge the mattress best suited for a customer's body type and sleeping position. The product is powered by "Sleep to Live" institute, an innovator in sleep science and technology in America. It is produced to help people pick up the right mattress and promote quality sleep. This advertisement is taken from youku

(http://v.youku.com/v_show/id_XNTM2OTc3MTcy.html), originally a video introducing the product and persuading retailors to buy this sales tool to attract customers. For our concern, the language used by the narrator will be the focus. The following analysis will reveal how "Sleep to Live" attempts to persuade audience to trust bedMATCH through presenting their good sense, good moral character and goodwill.

\section{Good Sense: Experience, Expertise and Authority}

This advertisement starts with introducing the sleeping problem of people and the consequences of lacking good sleep. "Science tells us that sleep deprivation compromises the immune system. It increases...it undermines our ability to live a healthy and long life." Their knowledge about sleeping can help to attract further attention of the audience. Also, explaining the reason for their developing bedMATCH, they show they know enough about the situation customers face in finding a right bed. "Your customers don't know how to pick a bed. They may flub down on four or five mattresses or they may spend 2 hours on your floor obsessing over the decisions. But as recent, exclusive, and exhaustive research shows, there is a very good chance they'll make the wrong call." These remarks suggest that they are well informed and thus very experienced about the issue.

Customers usually believe in experts, so the advertisers for "Sleep to Live" institute have to illustrate that they have expertise in this field. In the statement "It brings huge innovation to the business and science of sleep, backed by the technologies and engineering exclusive to Sleep to Live and its core is a simple but disruptive idea discovered by science", the words like "innovation", "science", "technologies", "engineering" prove that they are experts in this field.

In many statements, the illustration of expertise is also mingled with the demonstration of authority. "It's the only mattress diagnostics system certified by science, the only system supported by millions' dollars of research in some of the country's leading universities ... There's never been anything like it." "No one else offers it, no one else can or will." It can be found that through further showing their expertise, they are actually demonstrating that they are the most authoritative, as they have been supported by "leading universities", and also "by a research paper...previewed for the international press." The repeated "only", "no one else", and the word "never" in the above sentences, together with "sales staffs and retailors across the globe" evidently prove that the product is created and recognized by authorities.

\section{Good Moral Character: Justice, Honesty/Trustworthiness and Stateliness}

Justice is quite important in the world of business which is driven by profit, so "Sleep to Live" tries to project their image of fairness in order to identify with their audience's ideas. The institute is willing to offer retailors help to fight against those who are trying to commoditize the mattress business and those who sell products with cheap prices but of poor quality. Remarks such as "Fight back against those trying to commoditize the mattress business, introduce science into the selling equation across your whole floor. Beat back the little guys who are always trying to steal your sales with cheap prices" apparently present their fine image of fighting firmly against any unfair competitions.

While showing their expertise and authority, they are at the same time displaying their honesty and trustworthiness. In the video, they tend to emphasize that what they advocate in it is based on studies and researches, rather than irresponsible remarks: "as recent, exclusive, and exhaustive research shows..."; "In fact, according to the study..."; "the only system supported by millions' dollars of research". In addition, "science" is also their signal conveyed to audience, which means that what they say is scientific and that they are worthy of trust: "its core is a simple but disruptive idea discovered by science...."; "It's the only mattress diagnostic system certified by science."

Stateliness is another distinguishing character they display, which can be seen from the voice of the narrator, the subject he introduces and the language style the text presents. The narrator conveys the information with a low and sincere voice, moderately and impressively. Health, science and innovation are emphasized and focused on, which creates the 
atmosphere serious and academic. Moreover, the language used is generally formal, for there are several complex sentences (It affects our decision-making ability, our motor skills and it undermines our ability to live a healthy and long life, which is why we are introducing bedMATCH powered by Sleep to Live), participle phrases (backed by the technologies and engineering exclusive to Sleep to Live), and polysyllabic words (undermine, disruptive, exclusive), further establishing a stately image of the institution.

\section{Goodwill: Understanding, Empathy and Responsiveness}

Goodwill is another aspect obviously displayed in the ethos of this advertisement. Discussing sleeping problems to start the advertisement, the advertisers show their care for human sleep and health, which is a consideration and understanding of customers' needs. Meanwhile, in terms of what may happen in choosing the right mattress, they prove that the difficulties customers may experience are also considered and completely understood: "Your customers don't know how to pick a bed." Their goodwill toward customers may quickly draw the audience's attention and make them willing to listen.

For the potential problems bad sleep might bring and for the suffering of concerned customers, they express their deep empathy through the explanation of specific harms and the use of personal pronoun "our" (It affects our decision-making ability, our motor skills and it undermines our ability to live a healthy and long life), which indicates they regard the audience as intimate friends. Also, along with understanding of customers' needs of quality sleep and retailors' difficulties in competition, they generously express their willingness of providing help and empathetically show the same resentment against immoral competition.

Understanding and empathy are not enough; responsiveness with support is what customers really want. The statement "That's why we developed bedMATCH to take chance out of the equation once in for all" shows they know clearly about the needs of customers and they positively respond to them by developing a new product. Besides, they also promise to retailors as well as customers: "We now offer you the retailor, a uniquely flexible system that allows you to link the mattresses on your floor with our new bedMATCH diagnostic process... giving the retailor an incredibly powerful sales tool and giving the customers more choices and more ways to find the right mattress." They can give great support to the selling of their mattresses in addition to protecting retailors against potential unfair trading as shown above. Moreover, in the cooperation, they also offer "customized sales service", bring "higher profit margin values" to "best fit customers' needs", and help retailors drive demand and sales, which shows their positive and active responsiveness in the communication.

\subsection{Clinton's Speech in Beijing University}

On June 29, 1998, Clinton, American president at that time, addressed students in Beijing University, hoping to build a strong partnership between China and the United States in the new century. His good sense, good moral character and goodwill were constantly displayed in the speech to help him gain the understanding and support of his audience.

\section{Good Sense: Experience and Expertise}

As the speaker and the president, Clinton successfully proved that he was well informed about the rhetorical situation which involved his audience, Beijing University, China and the building of diplomatic relations. At the beginning of the speech, he showed his knowledge about the university, including the history of it, such as the May 4th movement led by the students, and the growth of it over the last 100 years. Turning to the country he was going to cooperate with, he spoke of the glorious past of China, the opening-up, the remarkable social and economic transformation, and the reactions of Chinese people. Focusing on his main purpose of this journey, he expressed what he knew about the development of the world, the changes brought by technologies and the challenges following. By specially mentioning the security in Asia threatened by the spread of deadlier nuclear, chemical, biological weapons, crime and drugs and environmental problems of China and the world, he demonstrated his extraordinary experience as an excellent speaker of diplomatic relations.

As Clinton said in the speech, the aim of his address was to inform students of the importance of "building a strong partnership between China and the United States". The fulfillment of this diplomatic purpose must be done through keen political judgment. Doubtlessly, Clinton has abundant expertise in this aspect. He could see through the complicated situation and make his own judgment regardless of what others may question: "I know there are those in China and the United States who question whether closer relations between our countries are a good thing. But everything all of us know about the way the world is changing and the challenges your generation will face tell us that our two nations will be far better off working together than apart." He could accurately point out the common challenges and seek the strongest partner based on them: "We, especially the younger generations of China and the United States, must make common cause of our common challenges, so that we can, together, shape a new century of brilliant possibilities." From the various challenges, he could discern those most critical and tough for his partner: "In the 21 st century, your generation must face the challenge of stopping the spread of deadlier nuclear, chemical, and biological weapons"; "In the 21 st century, your generation will have to reverse the international tide of crime and drugs...."; "In the 21 st century, your generation must make it your mission to ensure that today's progress does not come at tomorrow's expense...." As a persuader with a high political vision, he could make use of his advantages to achieve his goal: "We must work together. We Americans know from our own experience that it is possible to grow an economy 
while improving the environment. We must do that together for ourselves and for the world." In the face of the difficulties of this mission, he could find out the real reason, and set about solving them by first of all addressing the right people, those at the university level.

\section{Good Moral Character: Justice and Stateliness}

To achieve the goal of building a strong partnership, justice plays an important role. Most people think of America as arrogant and arbitrary, so Clinton tried to avoid such impression and project an image of justice. Firstly, he acknowledged the contributions China once did: "The American people deeply admire China for its thousands of years of contributions to culture and religion, to philosophy and the arts, to science and technology. We remember well our strong partnership in World War II." Then in evaluating the development of China, he did not exaggerate either its progress or its problems; instead, he judged them justly. Despite our miserable situation three decades ago, he complimented China for her remarkable changes and achievement; meanwhile, he did not try to magnify her development; but pointed out the problems objectively. And when discussing the Asia Pacific region with which China has many links, he emphasized that growth and prosperity should be embracing all of this region, which is a fair attitude towards all related nations.

Cheerful and lively as Clinton appears, stateliness presented in his ethos also enhances its persuasiveness. There are quite a few impressive parallel structures in this speech, which aided the speaker to sound very powerful and dignified: while explaining the main challenges this generation might face, he used three paragraphs beginning with "in the 21 st century"; to emphasize the strength of cooperation and their determination to fight against smugglers, he adopted three infinitive structures (to stop...); and when introducing the gift from China, he constructed three sentences starting with "these are the ideals", to show his strong feeling for the gift and for the ideal of freedom. Besides, the speech was elaborately organized, as long involved sentences were frequently employed, making his utterances sound compact, formal and rather stately: "I believe the kind of open, direct exchange that President Jiang and I had on Saturday at our press conference-- which I know many of you watched on television -- can both clarify and narrow our differences, and, more important, by allowing people to understand and debate and discuss these things can give a greater sense of confidence to our people that we can make a better future"; "Today we do not seek to impose our vision on others but we are convinced that certain rights are universal -- not American rights or European rights or rights for developed nations, but the birthrights of people everywhere, now enshrined in the United Nations Declaration on Human Rights -- the right to be treated with dignity; the right to express one's opinions, to choose one's own leaders, to associate freely with others, and to worship, or not, freely, however one chooses."

\section{Goodwill: Understanding, Empathy and Responsiveness}

Clinton's understanding toward his audience can be seen from many aspects. Firstly, he knew clearly about the past, the development and the challenges of China. Secondly, he understood the misgivings of Chinese people about the relationship between China and America: "I know there are those in China and the United States who question whether closer relations between our countries is a good thing." Thirdly, he could place himself in the position of Chinese people and point out the most urgent problems: "With borders on more than a dozen countries, China has become a crossroad for smugglers of all kinds"; "the cost is not only environmental, it is also serious in terms of the health consequences of your people and in terms of the drag on economic growth"; "The vibrant growth of your own economy is tied closely, therefore, to the restoration of stability and growth in the Asia Pacific region." Lastly, he could understand the expectations of Chinese people: "This new century can be the dawn of a new China, proud of your ancient greatness, proud of what you are doing, prouder still of the tomorrows to come."

In McCroskey's view, empathy is one person's identification with another person's feelings. To a large extent, cooperation means identification. At the beginning of the speech, Clinton tried to identify with his audience through Stanford, one of the schools with which Beijing University has a relationship, through its predecessor, Yenching University, which was founded by American missionaries, and through his Chinese congratulation on the centennial year of Beijing University. Those attempts showing the links between him and his audience quickly narrowed their distance. Besides, throughout the speech, he tried to show his empathy by identifying with Chinese culture, its glorious history, its contributions to the world, and its remarkable development. In addition, he constantly stood on the side of Chinese people to help us realize the tough challenges we might face in the near future, which also displayed his empathy toward the living conditions of Chinese people.

Responsiveness in ethos is also significant for the building of cooperation. At the beginning of his speech, Clinton actively recalled the delivery of the first commencement addressed by the first president of Yenching University, expressing his appreciation to present students and conveying his strong wish of talking to them. Based on everything he knew about China, he generously expressed his confidence and sincere wish to China and Chinese people: "Everything I know about the intelligence...give me confidence that you will succeed"; and "I believe your greatest days are still ahead." Harboring the expectation to the cooperation, Clinton appealed to Chinese people: "We, especially the younger generations of China and the United States, must make common cause of our common challenges, so that we can, together, shape a new century of brilliant possibilities." To respond to the anxiety and doubt of some 
people concerning the partnership, he made his standpoint clear: "But everything all of us know about the way the world is changing and the challenges your generation will face tell us that our two nations will be far better off working together than apart." Showing that he was willing to offer help, he mentioned that "President Jiang and I are working together on ways to bring American clean energy technology to help improve air quality and grow the Chinese economy at the same time." Finally, he tried to win the support of the students by pointing out the bright future of them as a result of the cooperation and expressing his high expectation toward them: "China has constantly proven the capacity to change and grow. Now, you must re-imagine China again for a new century, and your generation must be at the heart of China's regeneration."

\section{Conclusions}

This paper sets out to clarify the key elements of ethos and their respective basic sub-elements, so as to justify a concise hierarchical system of ethos-with an easier operability. Based upon the analyses of the available researches on ethos, this inquiry tentatively proposes a reframed model of ethos with Aristotle's elements of good sense, good moral character and goodwill, enriched respectively by three subelements for each: good sense (experience, expertise, authority); good moral character (justice, honesty, stateliness); goodwill (understanding, empathy, responsiveness). The principles of the component extraction are justified to ensure the validity and operability of the model. The analyses of the two texts have tested the effectiveness and flexibility of the reframed ethos model. Rhetors in the texts are found to have demonstrated various fine qualities presented in the model to win their audience's trust or support. Covering most of the key ethical qualities, this model proves to be facilitating in analyzing the persuasiveness of ethos.

\section{Acknowledgements}

We are very grateful to the peer review scholars for their appreciation and very constructive suggestions. Our gratitude also goes to Dr. Peter Zhang of Grand Valley State University for providing related references, and to $\mathrm{Mr}$. Mingan Luo for helping us design both the table and the diagram.

\section{REFERENCES}

[1] W. M. Sattler. Conceptions of ethos in ancient rhetoric. Speech Monographs, 14, 55-65, 1947.

[2] M. S. Halloran. Aristotle's concept of ethos, or if not his somebody else's. Rhetoric Review, 1(1), 58-63, 1982.

[3] T. S. Frobish. An origin of a theory: A comparison of ethos in the Homeric Iliad with that found in Aristotle's Rhetoric. Rhetoric Review , 22(1), 16-30, 2003.

[4] Aristotle. Rhetoric. (G. Kennedy, Trans.). New York: Oxford University Press, 2007.

[5] S. Brahnam. Building character for artificial conversational agents: Ethos, ethics, believability, and credibility. PsychNology Journal, 7(1), 9-47, 2009.

[6] C. Kallendorf, C. Kallendorf. The figures of speech, ethos, and Aristotle: Notes toward a rhetoric of business communication. Journal of Business Communication, 22(1), 35-50, 1985.

[7] D. Dean. Fear, negative campaigning and loathing: The case of the UK election campaign. Journal of Marketing Management, 21, 1067-1078, 2005.

[8] M. S. Cheng. Colin Powell's speech to the UN: A discourse analytic study of reconstituted ethos. Rhetoric Society Quarterly, 42(5), 424-449, 2012.

[9] F. Shanahan, P. Seele. Shorting Ethos: Exploring the Relationship Between Aristotle's Ethos and Reputation Management. Corporate Reputation Review, 18 (1), 37-49, 2015.

[10] B. Jorgensen. Nowhere motel, light beyond being. Journal of Education, 182(2), 55-66, 2000.

[11] Y. M. Liu. [刘亚猛],追求象征的力量. 北京:三联书店, 2004.

[12] W. X. Gong. [龚文庠], 说服学: 攻心的学问. 北京: 人民出版 社, 1994.

[13] M. M. Fan. [樊明明], 话语权力在两种文化中的结构和功 能: 中西古典修辞学中说服三要素比较. 外语学刊 (3): 28-32, 1999.

[14] C. Lan. [蓝纯], 修辞学:理论与实践. 北京:外语教学与研究 出版社, 2010.

[15] J. J. Tu. [涂家金],中美撞机事件修辞析.中国民航飞行学院 学报 18(5):44-47, 2007.

[16] K. Li. [李克],X. F. Liu. [刘新芳],修辞权威、修辞人格与修 辞劝说的互动关系研究: 基于一则汽车广告的分析. 中南 大学学报 17(4): 201-205, 2011.

[17] Y. M. Ju. [鞠玉梅] 英汉学术论文语篇中的元话语研究-从 亚里士多德修辞学的角度, 外语研究(3), 2013.

[18] Aristotle. Rhetoric. (W. R. Roberts, Trans.). New York: Random House, 1954.

[19] C. I.Hovland, I. L.Janis, H. H. Kelley. Communication and persuasion. New Haven: Yale University Press, 1953.

[20] W. McGuire. Attitudes and attitude change. G. Lindzey et al(ed). Handbook of Social Psychology. New York: Random House, 1985.

[21] R. Cockcroft, S. M. Cockcroft. Persuading people: An introduction to rhetoric. London: The Macmillan Press LTD, 1992.

[22] S. Crowley, \& D. Hawhee. Ancient rhetorics for contemporary students. Boston: Allyn and Bacon, 1994. 
[23] J. C.McCroskey, J. J. Teven. Goodwill: A reexamination of the construct and its measurement. Communication Monographs, 66(1), 90-103, 1999.

[24] J. C. McCroskey. An introduction to communication in the classroom. Edina: Burgess International Group, 1992.

[25] R. P. Hart, S. M. Daughton. Modern rhetorical criticism. Boston: Pearson Education, (Third Edition), 2005.
[26] R. P. Hart, G. W. Friedrich, W. D. Brooks. Public communication. New York: Harper, 1983.

[27] T. B. Farrell. Norms of rhetorical culture. New Haven, CT: Yale University Press, 1993.

[28] D. F. Shu. [束定芳], 现代语义学.上海: 上海外语教育出版 社, 2000. 